\title{
Analysis of Assessments of Low Frequency Noise from Wind Turbines. Calculations of Impact Range According to HN 30:2009
}

\author{
Darius Šaliūnas, Vitalijus Volkovas \\ Technological System Diagnostic Institute, Kaunas University of Technology, Lithuania \\ cross' $^{\text {ref }}$ http://dx.doi.org/10.5755/j01.erem.63.1.3303
}

(received in January, 2013, accepted in March, 2013)

\begin{abstract}
Since January 1, 2010, hygiene norm HN 30:2009 "Infrasound and low frequency sounds: Limit values for residential and public buildings" came into force in Lithuania. Project developers of economic activities (including developers of wind farms) face the problem how to assess correctly what infrasound and low frequency sounds levels will be met in the vicinity and how to not exceed limit values. Lithuania has no approved low frequency noise calculation method therefore the paper shortly reviews major issues of assessing low frequency noise from wind turbines, highlights its major problems, and also gives some recommendations for calculation of noise at low frequencies. Additionally, calculations of the distances from wind turbines where the exceeding of limit values could be met are presented. Calculations show that depending on a wind turbine in a plane terrain these distances can vary from $100 \mathrm{~m}$ to $2 \mathrm{~km}$ and more.
\end{abstract}

Keywords: wind turbine, low frequency noise, infrasound.

\section{Introduction}

Unwanted sound interfering with rest and work is treated as noise. Noise may affect humans, wildlife and structures. The limit values of sound pressure levels associated with the influence on human health are specified practically in all countries. Currently, mechanism of normal audible noise assessment and impact on human health is relatively well studied. There are a lot of calculation and assessment methods approved at the national (even international) level, as well as noise limit values, which usually are Aweighted. Meanwhile, low frequency noise as a problem more widely appeared under consideration only 15-20 years ago, when wind power industry all over the world came into rapid development. Thereby, the low-frequency noise effects on health are still intensely studied, also the legislation setting limit values and assessment methods are developed. Lowfrequency noise calculations and impact assessment are a new subject in Lithuania, and still there is a lack of information and methodology how calculations of indoor noise levels should be done considering the national legislation.

HN 30:2009 norm covers limit values in part of an infrasound and low frequency sound range from 8 to $200 \mathrm{~Hz}$. This norm sets limit values of infrasound and low frequency sounds inside residential and public buildings, and it is mandatory for legal and natural persons involved in design, realty building, creating/producing/implementing appliances or equipment, etc. One of the major reasons for implementation of this hygiene norm was a fast development of big industries and, particularly, development of wind farms in Lithuania. It should be noticed that Lithuania as well as other countries already has the overall A-weighted rated sound pressure limit values for residential and public environment and buildings (HN 33:2011).

Referencing recent literature, this paper shortly reviews main issues of assessing low frequency noise from wind turbines, highlights its major problems, and gives some points to the calculation of noise in low frequencies. To find how far the exceeding of low frequency noise limit values according to HN30:2009 can be met, the calculations based on wind turbine noise measurements performed by DELTA (Danish Electronics, Light an Acoustics company) have been made. 


\section{Methods}

For better understanding, the essence of the problem key issues concerning low frequency noise assessment is described. Afterwards, calculation results of low frequencies noise ranges considering the HN30:2009 limit values are presented.

\subsection{Low frequency sounds}

Generally, sound is classified into audible and inaudible. Considering that audible sound covers a range of $20 \mathrm{~Hz}-20 \mathrm{kHz}$, the sound below $20 \mathrm{~Hz}$ (in Lithuania, according to $\mathrm{HN} 30: 2009$, less than $16 \mathrm{~Hz}$ ) is described as infrasound, and higher than $20 \mathrm{kHz}$ as ultrasound. There is no single definition of what is a low frequency sound. Generally, it is considered that low frequency sounds are those up to $200-250 \mathrm{~Hz}$, the lowest frequency mean often overlap or overlay the infrasound range. What range of frequencies in different countries is named a low frequency sound often depends on the legally prescribed limit levels of the sound. For example, in Denmark the top meaning of the low frequency sound range is $160 \mathrm{~Hz}$, and the lowest - $10 \mathrm{~Hz}$ (WATANABE and Moeller 1990), (O’NEAL et al. 2009). Lithuanian HN 30:2009 norm says that low-frequency sound is defined as 16-200 $\mathrm{Hz}$ sound and infrasound is the sound of frequencies less than $16 \mathrm{~Hz}$.

\subsection{Limit values of infrasound and low frequency sounds}

Lithuania has no separate limit noise levels for wind turbines. Wind turbines' noise must comply with the limit values defined in norms HN33:2011 and HN30:2009. Limit values in hygiene norm HN 30:2009 are described by the rated sound pressure level at one-third octave band centre frequencies:

$$
L_{1 / 3 f, R}=L_{1 / 3 f, e q}+10 \lg \frac{T_{e}}{T_{R}}, d B
$$

where

$\mathrm{L}_{1 / 3 f, e q}$ - equivalent continuous sound pressure level at one-third octave band centre frequencies; $\mathrm{T}_{e}-\quad$ overall exposure duration of infrasound and

$\mathrm{T}_{\mathrm{R}}-\quad$ interval of evaluation time (day and evening time $\left(6-22 \mathrm{~h}\right.$.) evaluation time $T_{R}$ $=16$ h., night time $(22-6$ h. $)$ evaluation time $\mathrm{T}_{\mathrm{R}}=8 \mathrm{~h}$ ).

For using hygiene norm HN 30:2009 the following conditions should be met:

$\mathrm{L}_{\text {CeqT }} \geq 20 \mathrm{~dB}$, than $\mathrm{L}_{\text {AeqT }}$; (where $\mathrm{L}_{\text {AeqT }}$ and $\mathrm{L}_{\text {CeqT, }}$ respectively, $\mathrm{A}$ and $\mathrm{C}$ frequency weighted equivalent continuous sound pressure levels); or

$\mathrm{L}_{\text {CFmax }} \geq 20 \mathrm{~dB}$ than $\mathrm{L}_{A \text { max }}$. (where $\mathrm{L}_{\text {CFmax }}$ and $\mathrm{L}_{\text {AFmax }}$, respectively, $\mathrm{A}$ and $\mathrm{C}$ frequency and $\mathrm{F}$ time weighted maximum sound pressure levels).

In the other case, only limit values of Aweighted maximum and equivalent continuous sound pressure levels according to HN 33:2011 should not be exceeded. The amplitude correction as a function of frequency $f$ in $\mathrm{Hz}$ for weighting filters $\mathrm{A}$ and $\mathrm{C}$ can be found following the equations (LST EN 61672$1: 2003)$ :

$$
\begin{aligned}
& A=20 \cdot \log \left(\frac{12200^{2} \cdot f^{4}}{\left(f^{2}+20,6^{2}\right) \cdot\left(f^{2}+12200^{2}\right) \cdot \sqrt{\left(f^{2}+107,7^{2}\right)} \cdot \sqrt{\left(f^{2}+737,9^{2}\right)}}\right)+2,00, d B \\
& C=20 \cdot \log \left(\frac{12200^{2} \cdot f^{4}}{\left(f^{2}+20,6^{2}\right) \cdot\left(f^{2}+12200^{2}\right)}\right)+0,06 d B
\end{aligned}
$$

Table 1. Limit values of infrasound and low frequency sound in living and public dwellings (indoors)

\begin{tabular}{||l|c|c|c|c|c|c|c|c|c|c|c|c|c|c|c||}
\hline $\begin{array}{l}\mathbf{1 / 3} \text { octave band } \\
\text { centre } \\
\text { frequencies, Hz }\end{array}$ & $\mathbf{8}$ & $\mathbf{1 0}$ & $\mathbf{1 2 , 5}$ & $\mathbf{1 6}$ & $\mathbf{2 0}$ & $\mathbf{2 5}$ & $\mathbf{3 1 , 5}$ & $\mathbf{4 0}$ & $\mathbf{5 0}$ & $\mathbf{6 3}$ & $\mathbf{8 0}$ & $\mathbf{1 0 0}$ & $\mathbf{1 2 5}$ & $\mathbf{1 6 0}$ & $\mathbf{2 0 0}$ \\
\hline $\begin{array}{l}\mathrm{L}_{\text {l/3f,eq }} \text { limit values, } \\
\mathrm{dB}\end{array}$ & 103 & 95 & 87 & 79 & 71 & 63 & 56 & 48 & 41 & 34 & 28 & 24 & 21 & 17 & 14 \\
\hline $\begin{array}{l}\text { Hearing threshold } \\
\text { according to ISO } \\
226\end{array}$ & & & & & 78.5 & 68.7 & 59.5 & 51.1 & 44 & 37.5 & 31.5 & 26.5 & 22.1 & 17.9 & 14.4 \\
\hline
\end{tabular}

* for tonal noise the limit values reduce in $5 \mathrm{~dB}$.

In some other countries (Denmark, Sweden, Netherlands, etc.) separate limit values of $\mathrm{L}_{\text {Aeq }}$ are used for wind turbines.

\subsection{Characteristics of wind turbines noise}

Measurements and data aggregation of a number of wind turbines were carried out in Denmark by DELTA (Danish Electronics, Light an Acoustics) for Danish Energy Authority (MØLLER 2011), 
(MADSEN 2010). A-weighted spectrums of 62 wind turbines sound power levels are presented in Figure 1. Low frequency noise emission from large (> $2 \mathrm{MW}$ ) wind turbines is slightly higher than that from smaller
( $\leq 2$ MW) ones (PEDERSEN et al. 2012), (JAKOBSEN 2012), the levels between turbines vary by $20 \mathrm{~dB}$ or even more.

Table 2. Limit values of sound according to HN33:2011

\begin{tabular}{||l|c|c|c||}
\hline & $\begin{array}{c}\text { Time period, } \\
\text { h. }\end{array}$ & $\begin{array}{c}\text { Equivalent Sound } \\
\text { pressure level }\left(\mathbf{L}_{\mathbf{A e q T}}\right), \mathbf{d B A}\end{array}$ & $\begin{array}{c}\text { Maximum Sound } \\
\text { pressure level }\left(\mathbf{L}_{\mathbf{A F m a x}}\right), \\
\mathbf{d B A}\end{array}$ \\
\hline Residential and public premises, & $6-18$ & 45 & 55 \\
bedrooms, personal health care & $18-22$ & 40 & 50 \\
premises & $22-6$ & 35 & 45 \\
\hline Residential and public use land (for & $6-18$ & 55 & 60 \\
all noise sources except transport & $18-22$ & 50 & 55 \\
noise) & $22-6$ & 45 & 50 \\
\hline
\end{tabular}

Table 3. $\quad$ Limit values of sound in some other countries LAeq or Lden for wind turbines (data from (JABBEN and Verheijen 2012),(JAKOBSEN 2012),( MCALEER 2011), (Van der BERG 2011))

\begin{tabular}{|c|c|}
\hline Country & Limit values \\
\hline Denmark & $\begin{array}{l}\text { The total noise level from wind turbines should not exceed the following limit values: } \\
\text { - At the most noise-exposed point in outdoor living area no more than } 15 \text { metres from } \\
\text { dwellings in the open countryside: } \\
\text { (a) } 44 \mathrm{~dB}(\mathrm{~A}) \text { at a wind speed of } 8 \mathrm{~m} / \mathrm{s} \text {. } \\
\text { (b) } 42 \mathrm{~dB}(\mathrm{~A}) \text { at a wind speed of } 6 \mathrm{~m} / \mathrm{s} \text {. } \\
\text { - At the most noise-exposed point in areas with noise-sensitive land use: } \\
\text { (a) } 39 \mathrm{~dB}(\mathrm{~A}) \text { at a wind speed of } 8 \mathrm{~m} / \mathrm{s} \text {. } \\
\text { (b) } 37 \mathrm{~dB}(\mathrm{~A}) \text { at a wind speed of } 6 \mathrm{~m} / \mathrm{s} \text {. } \\
\mathrm{L}_{\mathrm{pA}(10-160 \mathrm{~Hz})}=20 \mathrm{~dB} \text { indoor sound pressure level from wind turbines at wind speeds of } 6 \\
\text { and } 8 \mathrm{~m} / \mathrm{s}\end{array}$ \\
\hline Sweden & $\mathrm{L}_{\text {night }}$ limit of $40 \mathrm{~dB}(\mathrm{~A})$ at a wind speed of $8 \mathrm{~m} / \mathrm{s}$ (at 10 metres height). \\
\hline Netherlands & $\begin{array}{l}\text { Wind turbine noise is restricted to an } \mathrm{L}_{\mathrm{den}} \text { value of } 47 \mathrm{dBA} \text { and an } \mathrm{L}_{\text {night }} \text { value of } 41 \mathrm{dBA} \text {. } \\
\text { Preferred } \mathrm{L}_{\mathrm{den}} \text { value of } 40 \mathrm{dBA} \text {. }\end{array}$ \\
\hline $\begin{array}{l}\text { Germany, Italy, } \\
\text { Portugal, Spain }\end{array}$ & $\begin{array}{l}\text { No specific wind turbine noise guidance is available therefore the generic limits are } \\
\text { applied. }\end{array}$ \\
\hline
\end{tabular}

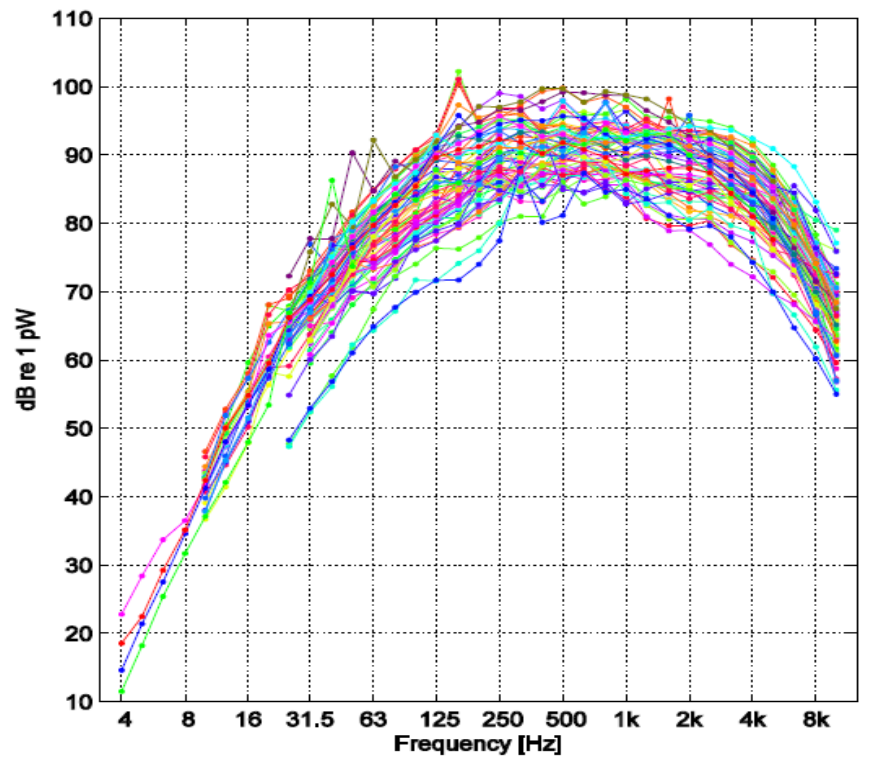

Fig. 1. A-weighted apparent sound power levels in 1/3 octave bands of 62 turbines with nominal electrical power of $75 \mathrm{~kW}$ to 3.6MW (PEDERSEN et. al. 20012)

Looking at Figure 1, some interference can be drawn: wind turbines generate low frequency noise but the dominant levels (from a point of human hearing) are mid frequencies in a range of 200$2000 \mathrm{~Hz}$. Despite dominant mid frequencies, low frequencies can have a big influence on annoyance 
and health of people. Also "wind turbines emit infrasound, but levels are low when human sensitivity to these frequencies is accounted for. Even close to the turbines, the sound pressure level is much below the normal hearing threshold, and infrasound is thus not considered a problem with turbines of the investigated size and construction" (PEDERSEN et al. 2012).

"Some of the turbines have a peak in one or more one-third-octave bands, which may be due to the presence of tonal components. Tones are likely to have their origin in the turbine mechanics, e.g. the gearbox or secondary equipment such as a generator cooling system (see e.g. Wagner et al." (PEDERSEN et al. 2012). "This noise can occur both at low and higher frequencies, typically tones in wind turbine noise is seen in the range between 40 and $500 \mathrm{~Hz}$ " (JAKOBSEN 2012). Also sometimes tonality is not present in outdoor sound from wind turbines, but indoor measurements can show it. This can be explained by effect to the forming standing waves at eigenfrequencies of rooms, notably in the order of 30$100 \mathrm{~Hz}$. (JABBEN and Verheijen 2012).

The sound of wind turbines is fluctuating (described by residents with terms "swishing", "clapping", "thumping" and "low-frequency noise"). Modulation of the sound of wind turbines depends on the blade passing hub frequency. "Typical variation in the blade passing frequency for modern 3 blade turbines is between 0.5 and $1.5 \mathrm{~Hz}$ " (LENCHINE 2009). It is difficult to name the character of wind turbine's sound whether it is impulsive or not. One fact is sure - it is not as impulsive as gun shots or hammering, but it has a character of impulsivity (KERKERS and Koffeman 2002), (VAN DEN BERG 2006).

\subsection{The principal scheme of indoor noise evaluation from outdoor noise}

The main task for project developers dealing with assessment of normal noise as well as infrasound and low frequency sounds field transformations can be divided into 4 steps:

Step 1 Sound power level identification of noise source (in our case at 1/3 octave band centre frequencies);

Step 2 Identification of outdoor sound field transformation;

Step 3 Identification of noise reduction through house construction; level.

Step 4 Identification of indoor sound pressure

Step 1. The sound power level cannot be measured directly but it is calculated from sound pressure level data. Identification of the noise source sound power level for a new activity (not installed) can be done looking at the equipment specifications or by measurements of analogical equipment. The sound power level (SPL) estimation can be done following the standards, which are selected by the source of noise (standards approved in Lithuania: ISO 3745:2003, ISO 13347-3:2004, ISO 3743-1:2010, ISO 3744:2010, ISO 3746:2010, IEC TS 61400-14, etc.) or by a possibility to measure sound pressure levels in various environment. The problem is that the standards for other sources than wind turbines do not describe SPL measurement spectre, which is required to make infrasound and low frequency noise measurements. For example, standard LST EN ISO $3744: 2011$ refers to $125-8000 \mathrm{~Hz}$ one octave band or $100-10000 \mathrm{~Hz} \mathrm{1/3}$ octave band spectrum, which could be modified, if there is a demand.

Talking about wind turbines, according Broneske (BRONESKE 2009), the format, in which sound power levels are provided with possible uncertainties, differs from manufacturer to manufacturer. For noise calculations it would be preferable to get sound power levels in accordance with IEC TS 61400-14 standard. According to SØRENSEN (SØRENSEN 2012), acquisition of formal low frequency noise data from manufacturers of wind turbines presents difficulties, because the data are considered as a trade secret, also because "uncertainty on the $1 / 3$ octave data in the low frequency area is so large that they cannot be warranted and the turbine manufacturers do not wish to be held liable for them".

If we do not have wind turbine sound power levels at one third octaves agreeably to IEC TS 61400-14, measurements should be carried out according to LST EN 61400-11:2003. Measurements according to the standard give sound power pressure levels in the frequency range of $50-10000 \mathrm{~Hz}$ or even down to $20 \mathrm{~Hz}$ in case of significant low frequency noise (according to Annex A), but it can be extended for infrasonic frequencies also. Some literature (like SONDERGAARD 2008) recommends using a secondary wind screen reducing background noise at low frequencies which are worst at frequencies below $50 \mathrm{~Hz}$.

The sound power level is calculated according to the equation below:

$L_{W . o c t . c}=L_{e q . o c t . c}-6+10 \lg \left[\frac{4 \pi \cdot R_{1}^{2}}{S_{0}}\right]$

where:

$\mathrm{L}_{\text {eq.oct. }}{ }^{-} \quad$ background noise corrected sound pressure level in $1 / 3$ octaves at the integer wind speeds and under reference conditions;

$R_{1}-\quad$ slant distance in meters from the rotor centre to the microphone;

$S_{0}-\quad$ reference area, $S_{0}=1 \mathrm{~m}^{2}$

Step 2. Noise propagation outdoors is influenced by meteorological conditions, such as atmospheric absorption and refraction, wind speed, direction and turbulence, also temperature and humidity. The best conditions for noise propagation are in the wind direction, when the temperature inversion (which induces sound wave refraction from upper air layers) conditions are met, normally such conditions are at 
night time with the bright sky (no clouds). Talking about wind turbines, "there is a distinct audible difference between the night and daytime wind turbine sound at some distance from the turbines. On a summer's day in a moderate or even strong wind the turbines may only be heard within a few hundred meters. However, on quiet nights the wind park can be heard at distances up to several kilometres when the turbines rotate at high speed" (Van den BERG 2004). Atmospheric absorption is actual for mid and high frequencies noise and has little influence on reduction of SPL in low frequencies. "This means that as a sound travels, its frequency content alters making the low frequencies more prominent at greater distances."(CASELLA STANGER 2001).

To identify the outdoor sound, field transformation measurements of the existing situation can be made. However, for the planned activity the noise transformation calculations should be done. Referencing to (PLOVSING 2008), noise propagation (field transformation) calculation models (methods) can be divided into three groups:

- Empirical models (practical engineering methods (ISO 9613-2, BNPM, Nordic, etc.));

- Ray tracing models (numerical ray tracing models and semi-analytical models);

- Wave equation models (parabolic equation method (PE), boundary element method (BEM), finite element method (FEM), fast field program (FFP), linearized Euler method (EU)).

All of the methods have advantages and weaknesses. Lithuania has no approved noise calculation method, except for strategic noise mapping (politically accepted, but not verified and engrafted) for agglomerations, main roads, railways,

$L_{p A(\text { outddor })}=L W_{\text {WA.ref }}-20 d B \cdot \log _{10}\left(\frac{d}{1 m}\right)-11 d B+\Delta L_{g}-\Delta L_{a}$

Where:

$L_{W A, r e f}$ - apparent sound power level in the reference direction, basically measured according to IEC 61400-11, $d$ - distance from the nacelle to the receiver,

$\Delta L_{g}$ - correction for the ground reflection,

$\Delta L_{a}-\quad$ air absorption equal to $\alpha_{\mathrm{a}} \cdot \mathrm{d}$, where $\alpha_{\mathrm{a}}$ is the absorption coefficient.

Table 4. Key figures for calculation of low frequency noise levels from new Danish regulations (PEDERSEN et. al. 2012)

\begin{tabular}{||c|c|c|c|c|c|c|c|c|c|c|c|c|c||}
\hline Frequency, $\mathrm{Hz}$ & $\mathbf{1 0}$ & $\mathbf{1 2 , 5}$ & $\mathbf{1 6}$ & $\mathbf{2 0}$ & $\mathbf{2 5}$ & $\mathbf{3 1 , 5}$ & $\mathbf{4 0}$ & $\mathbf{5 0}$ & $\mathbf{6 3}$ & $\mathbf{8 0}$ & $\mathbf{1 0 0}$ & $\mathbf{1 2 5}$ & $\mathbf{1 6 0}$ \\
\hline$\Delta \mathrm{L}_{\mathrm{g}}$ (land), dB & 6.0 & 6.0 & 5.8 & 5.6 & 5.4 & 5.2 & 5.0 & 4.7 & 4.3 & 3.7 & 3.0 & 1.8 & 0.0 \\
\hline$\Delta \mathrm{L}_{\mathrm{g}}(\mathrm{sea}), \mathrm{dB}$ & 6.0 & 6.0 & 6.0 & 6.0 & 6.0 & 5.9 & 5.9 & 5.8 & 5.7 & 5.5 & 5.2 & 4.7 & 4.0 \\
\hline$\alpha_{\mathrm{a},} \mathrm{dB} / \mathrm{km}$ & 0 & 0 & 0 & 0 & 0.02 & 0.03 & 0.05 & 0.07 & 0.11 & 0.17 & 0.26 & 0.38 & 0.55 \\
\hline
\end{tabular}

Another way to get infrasonic values, when computer calculations are done either with Nord 2000 or Harmonoise method, is to take into account the difference of sound power levels and $\Delta \mathrm{L}_{\mathrm{g}}$ between the calculated lowest frequencies band $(25 \mathrm{~Hz})$ and the infrasonic band of interest.

Step 3. Normally, building construction also windows efficiently attenuate noise up to $40 \mathrm{~dB}$ or even more at mid and high frequencies. However, airports, and industry according to Directive 2002/49/EC.

Empirical methods are based on measurements. Most wind turbines noise calculations are done using empirical models, which are in the commercial software, and most popular of them is ISO 9613-2. The method is used for industry, but has some restrictions (like calculation accuracy from the distance more than $1 \mathrm{~km}$ or elevated noise sources) therefore it does not give good results for wind turbines.

Wave equation models are numerical methods based on wave equation solution. According to Madsen (MADSEN 2010), only one relevant method can be considered - it is a parabolic equation method. However, this method takes a long time of calculation and it is convenient only in cases of specific weather conditions or long distances ( $1 \mathrm{~km}$ and more), when alculations have to be accurately done.

According to Plovsing (PLOVSING 2008), ray cing methods based on ray acoustics are more for homogeneous atmosphere without refraction. In refracting atmosphere and complex terrain the results are not so accurate. Most relevant semi-analytical methods are Nord 2000 and Harmonoise. For calculation of outdoor wind turbine noise propagation, Danish experts recommend using Nord 2000 method because of its expertise and a lot of measurements for method verification (PLOVSING 2008). In this paper Harmonoise (method is prepared on the base of Nord 2000) within ADNA A commercial software is used.

To calculate the infrasound levels, the equation from new Danish regulations (DME 2011) for wind turbines can be taken. According to these regulations,

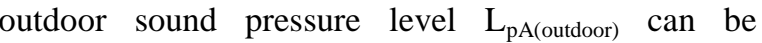
calculated using equation (5):

attenuation in low frequencies is much more complicated. Furthermore, standards for sound energy attenuation through constructions do not embrace low frequencies. For example, LST EN 12354-3 describes construction noise attenuation in a range of 125 $2000 \mathrm{~Hz}$. There are some studies in the world about low frequency noise attenuation of typical houses. The studies show that there are cases when the indoor sound pressure level is greater than that of outdoor 
(see Step 4), but, in general, for example according to (HOFFMEYER and Jakobsen 2010), in 80-90\% of
Danish houses difference between the outdoor and indoor sound pressure level is $1.2-22.4 \mathrm{~dB}$ (Table 5)

Table 5. Level difference in $\mathrm{dB}$ expected to be exceeded in $80-90 \%$ of typical Danish dwellings

\begin{tabular}{|l|l|l|l|l|l|l|l|l|l|l|l|l|l|l|l||}
\hline $\begin{array}{l}\text { one-third } \\
\text { octave band } \\
\text { centre } \\
\text { frequencies, } \\
\text { Hz }\end{array}$ & 8 & 10 & 12.5 & 16 & 20 & 25 & 31.5 & 40 & 50 & 63 & 80 & 100 & 125 & 160 & 200 \\
\hline $\begin{array}{l}\text { Difference } \\
\text { between } \\
\text { outdoor and } \\
\text { indoor SPL, } \\
\text { dB }\end{array}$ & 2.4 & 1.2 & 3.2 & 2.1 & 3.6 & 4.6 & 6.7 & 7.6 & 10.3 & 14.2 & 17.5 & 18.4 & 17.5 & 18.6 & 22.4 \\
\hline $\begin{array}{l}\text { Danish } \\
\text { wind } \\
\text { turbine } \\
\text { noise } \\
\text { regulations, } \\
\text { LF-noise }\end{array}$ & & 4.9 & 5.9 & 4.6 & 6.6 & 8.4 & 10.8 & 11.4 & 13.0 & 16.6 & 19.7 & 21.2 & 20.2 & 21.2 & \\
\hline
\end{tabular}

Referencing to (PEDERSEN et. al. 20012), ”the new Danish regulations on noise from wind turbines underestimate the indoor levels of low-frequency noise, mainly due to the use of too large sound insulation numbers for frequencies above $63 \mathrm{~Hz}$, where the low-frequency noise from large wind turbines is most dominating and most audible".

Step 4. For calculations of the indoor SPL distribution there are a lot of software, like DataKustik Bastian (according to EN 12354-1, EN 12354-2, EN 12354-3) or Cadna G (methods: diffuse field, mirror image method, particle model, VDI 3760). Accurate results can be achieved using numerical wave equation methods.

To compare indoor noise levels with limit values, it is very important to choose right positions of SPL identification at low frequencies. "Sound pressure levels (SPL) at low frequencies $(20$ to $200 \mathrm{~Hz}$ ) are strongly dependent on measurement position in normal-sized rooms. The variation of SPL can be above $20 \mathrm{~dB}$ between different measurement locations" (OLIVA et al. 2011). Such a big SPL difference indoors appears at eigenfrequencies of a room - "the sound wave, examined in a certain point, returns to the same point after two or more reflections from the room boundaries and interferes with the original sound wave in the same phase. The sound travels the same path ideally infinite times. As a result of this, the sound pressure level depends strongly on location." (OLIVA et al. 2011). An example from (OLIVA et al. 2011) of low frequency SPL distributing in room space (room modes produce large variation of SPLs within a room) is placed below (modelling was made using Comsol 3.5a software Finite Element Method (FEM)).

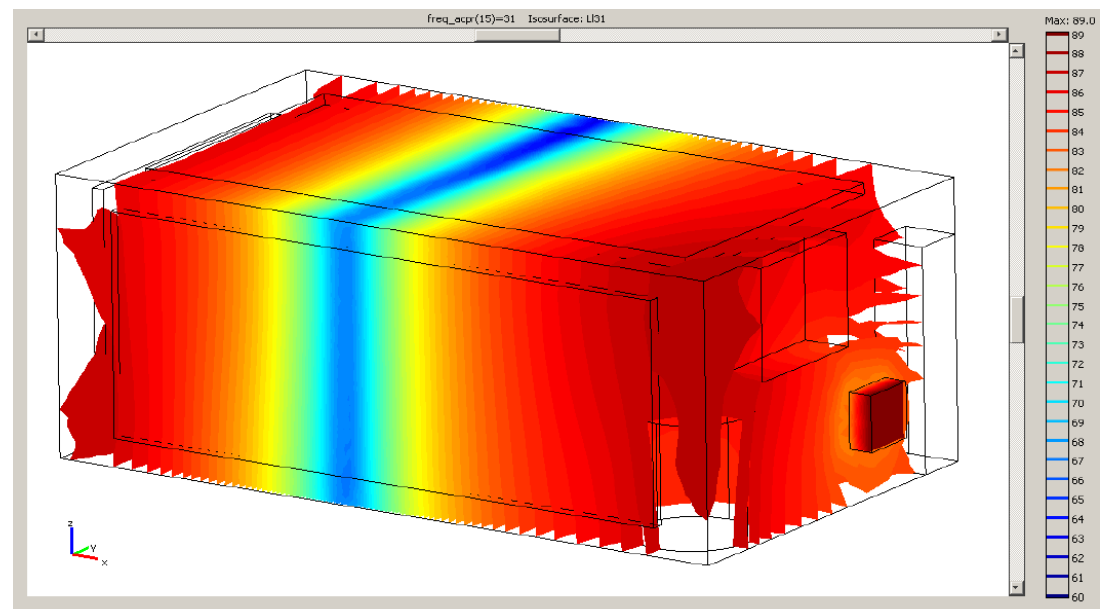

Fig 2. A hypothetical room of $6 \times 4 \times 2.5 \mathrm{~m}$ Red area is the plane sound source. SPL at 1/3-octave 31 Hz. SPL scale is between 89 and $60 \mathrm{~dB}$. (OLIVA et al. 2011)

Hygiene norm HN 30:2009 appoints measurements of low frequency noise according to LST ISO 1996-2:2008. According to this standard, measurements should be made at 3 points, one of them in a corner at a distance $0.5 \mathrm{~m}$ from the ceiling and walls. Other 2 points are selected at least at $0.5 \mathrm{~m}$ 
from the walls, etc. Table 6 presents comparison of measurement methods in different countries.

LST ISO 1996-2:2008 do not talk about the window position: should it be open or closed. For example, "in Denmark, indoor measurements of lowfrequency noise are usually made with closed windows, but if the complainant finds that the noise is louder with open windows, measurements should also be made for this situation" Danish Environmental Review (DEPA 1997) and also World Health Organisation (WHO) recommend that noise limits should permit with the windows at least slightly open (Berglund et al. 2011), (WHO 2009). Lithuanian National Public Health Surveillance Laboratory keeps to this recommendation when measuring noise at low frequencies, too.

Table 6. Summary of measurement methods in different countries, according to (ISO 1996-2:2007), (OLIVA et al. 2011),(BRONESKE2009)

\begin{tabular}{||l|l|l|l|l|l|l|l||}
\hline Country & Standard & $\begin{array}{l}\text { Number of } \\
\text { measurement } \\
\text { locations }\end{array}$ & $\begin{array}{l}\text { Octave } \\
\text { bands }\end{array}$ & $\begin{array}{l}\text { Points } \\
\text { in } \\
\text { corner }\end{array}$ & $\begin{array}{l}\text { Frequency } \\
\text { Range, Hz }\end{array}$ & $\begin{array}{l}\text { Minimum } \\
\text { distance } \\
\text { to walls }\end{array}$ & $\begin{array}{l}\text { Height, } \\
\mathrm{m}\end{array}$ \\
\hline Sweden & SP INFO 1996:17 & 3 & $1 / 3$ & $\begin{array}{l}1 \\
\text { corner }\end{array}$ & $31.5-200$ & 0.5 & $\begin{array}{l}0.6 ; 1.2 \\
1.6\end{array}$ \\
\hline Denmark & Nr. 9 1997 & 3 & $1 / 3$ & $\begin{array}{l}1 \\
\text { corner }\end{array}$ & $5-160$ & 0.5 & - \\
\hline Germany & DIN 45680 & 1 & $1 / 3$ & - & $10-80$ & & - \\
\hline Austria & ÖNORM S 5007 & 1 & $1 / 3$ & - & $10-80$ & - & - \\
\hline Netherlands & NSG 1999 & 1 & $1 / 3$ & $\begin{array}{l}1 \\
\text { corner }\end{array}$ & $20-100$ & $0.2-0.5$ & - \\
\hline USA & ANSI S 12.9 Part 1 & multiple & $1 / 3$ & corner & - & - & - \\
\hline Finland & $\begin{array}{l}\text { Asumisterveysohje } \\
2003\end{array}$ & multiple & $1 / 3$ & - & $20-200$ & 1 & - \\
\hline Lithuania & $\begin{array}{l}\text { LST ISO 1996- } \\
2: 2008\end{array}$ & 3 & $1 / 3$ & $\begin{array}{l}1 \\
\text { corner }\end{array}$ & $8-200$ & 0.5 & $>1$ \\
\hline
\end{tabular}

Bearing in mind that there is no big difference between Danish and Lithuanian LF noise measurement standards, to obtain calculations corresponding to the HN 30:2009 requirements the authors recommend to apply the outdoor-indoor SPL difference from Table 5, row 2 (HOFFMEYER and Jakobsen 2010). In order to get more accurate results of indoor SPL (e.g. for certain locations of the room) more advanced methods should be used (e.g. finite element method FEM).

\section{Results and Discussion}

Summarizing the paper material above, the question arises what distances from a new wind turbine could be met ensuring that the limit values of low frequency noise and infrasound in the vicinity will not be exceeded. Referencing to (SØRENSEN 2012) EMD WindPro (software for wind energy project design and planning) specialists did calculations on 4 wind turbines to compare the distances for meeting Danish normal (44 dBA) and low frequency $\left(\mathrm{L}_{\mathrm{pA}(10-160 \mathrm{~Hz})}=20 \mathrm{~dB}\right.$ indoor) noise limit values. The study showed that 3 from 4 wind turbines had the distance for normal noise greater than for low frequency noise limit values. 1 turbine had the distance of low frequency noise greater than for normal noise limit value. In the latter case it is calculated that the distance of low frequency noise limit value $\mathrm{L}_{\mathrm{pLF}}(20 \mathrm{dBA})$ will be $435 \mathrm{~m}$, and for normal noise $\mathrm{L}_{\mathrm{eq}}(44 \mathrm{dBA}) 372 \mathrm{~m}$ from a hub. For 5 wind turbines (placed in the distance of 5 rotor diameters) the distance from a centre turbine will be $813 \mathrm{~m}$.

Until in Lithuania there is no research on determining how far away the low frequency noise limit values (according HN30:2009) will not be exceeded, data from Figure 1 were used. To determine what maximum distance could be, a top contour from 62 wind turbines of sound power levels curves was taken. Also A-weighting coefficient was taken into account. To calculate indoor levels for hypothetical noise attenuation by house construction, the values from Table 5 (row 2) and from an acoustic insulation curve of "Saint Gobain" windows (as a weakest part of construction) were taken. Calculations are presented in Table 7. Similarly, calculations for the minimum distance of a few wind turbines were done and conclusions were included in this paper.

Calculations were made using DataKustik Cadna A software and Harmonoise method. Initial conditions were: plane and absorbing terrain, temperature $10^{\circ} \mathrm{C}$, rel. humidity $70 \%$, wind speed $8 \mathrm{~m} / \mathrm{s}$, stability class S3. For frequencies less than $25 \mathrm{~Hz}$, the difference of sound power levels and $\Delta \mathrm{L}_{\mathrm{g}}$ between calculated lowest frequencies band $(25 \mathrm{~Hz})$ and infrasonic band of interest was taken into account. 
Calculation data to determine maximum distance ensuring that low frequency noise limit values will not be exceeded (according toHN30:2009) from a hypothetical (most noisy) wind turbine in a hypothetical house

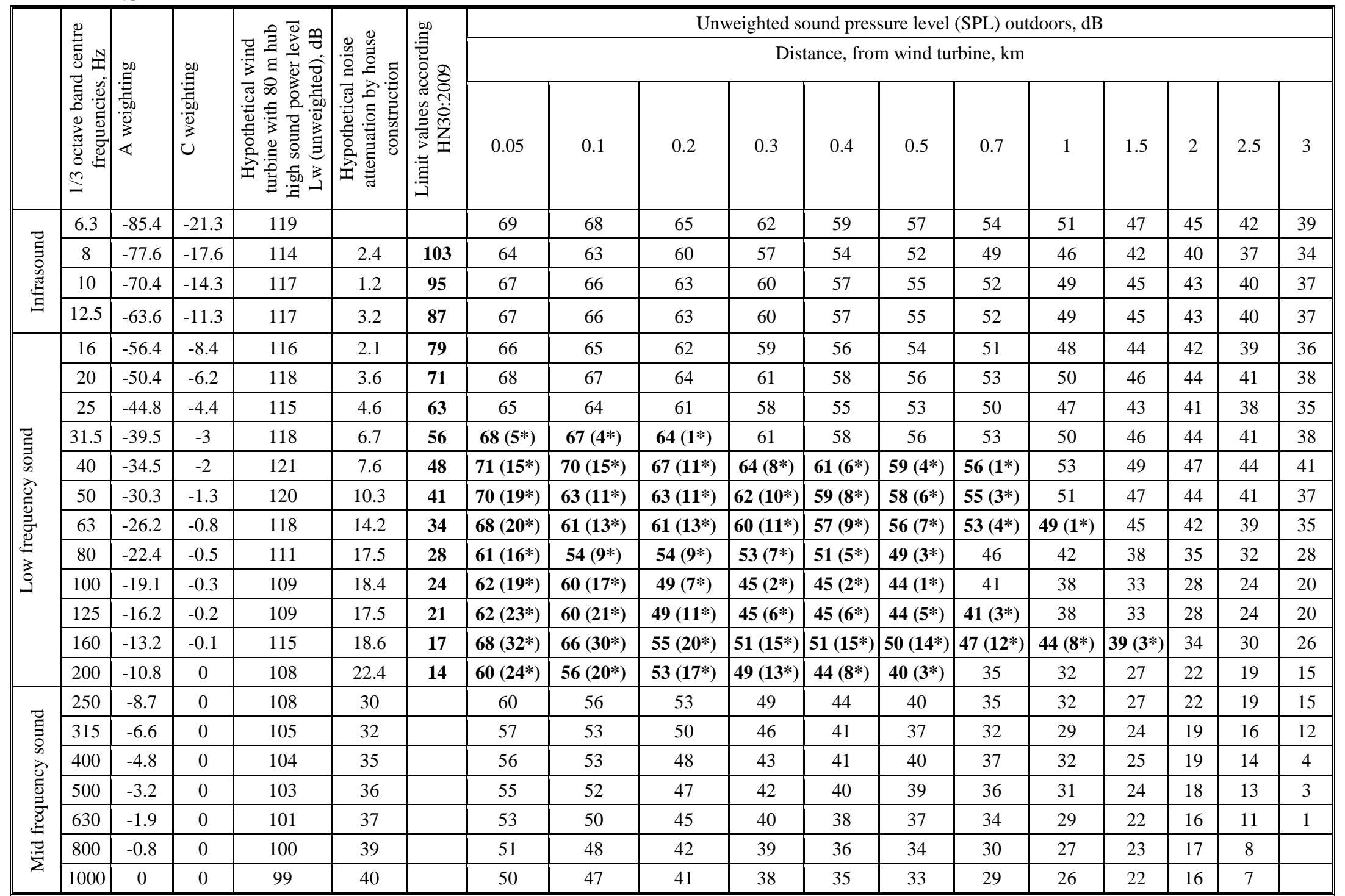




\begin{tabular}{|c|c|c|c|c|c|c|c|c|c|c|c|c|c|c|c|c|c|c|}
\hline \multirow{5}{*}{$\mid$} & \multirow{3}{*}{ 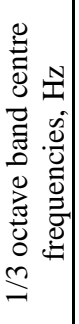 } & \multirow{3}{*}{$\begin{array}{l} \\
60 \\
.0 \\
0 \\
0.00 \\
0 \\
0 \\
3 \\
4\end{array}$} & \multirow{3}{*}{ 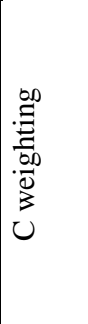 } & \multirow{3}{*}{ 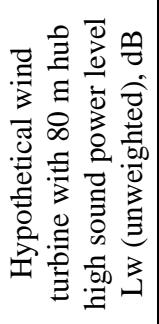 } & \multirow{3}{*}{ 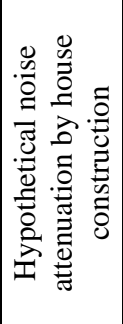 } & \multirow{3}{*}{ 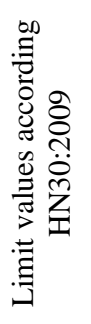 } & \multicolumn{12}{|c|}{ Unweighted sound pressure level (SPL) outdoors, dB } \\
\hline & & & & & & & \multicolumn{12}{|c|}{ Distance, from wind turbine, $\mathrm{km}$} \\
\hline & & & & & & & 0.05 & 0.1 & 0.2 & 0.3 & 0.4 & 0.5 & 0.7 & 1 & 1.5 & 2 & 2.5 & 3 \\
\hline & 1250 & 0.6 & 0 & 97 & 41 & & 48 & 45 & 39 & 36 & 33 & 31 & 27 & 24 & 20 & 14 & 5 & \\
\hline & 1600 & 1 & -0.1 & 97 & 37 & & 47 & 44 & 38 & 34 & 31 & 28 & 23 & 19 & 11 & 5 & & \\
\hline \multirow{8}{*}{ 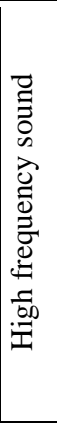 } & 2000 & 1.2 & -0.2 & 95 & 35 & & 45 & 42 & 36 & 32 & 29 & 26 & 21 & 17 & 9 & 3 & & \\
\hline & 2500 & 1.3 & -0.3 & 94 & 36 & & 44 & 41 & 35 & 31 & 28 & 25 & 20 & 16 & 8 & 2 & & \\
\hline & 3150 & 1.2 & -0.5 & 93 & 40 & & 40 & 36 & 29 & 23 & 19 & 15 & 7 & & & & & \\
\hline & 4000 & 1 & -0.8 & 91 & 45 & & 38 & 34 & 27 & 21 & 17 & 13 & 5 & & & & & \\
\hline & 5000 & 0.6 & -1.3 & 90 & & & 37 & 33 & 26 & 20 & 16 & 12 & 4 & & & & & \\
\hline & 6300 & -0.1 & -2 & 90 & & & 30 & 24 & 12 & 2 & & & & & & & & \\
\hline & 8000 & -1.1 & -3 & 85 & & & 25 & 19 & 7 & & & & & & & & & \\
\hline & $\begin{array}{c}1000 \\
0\end{array}$ & -2.5 & -4.4 & 82 & & & 22 & 16 & 4 & & & & & & & & & \\
\hline \multicolumn{7}{|c|}{ Total outdoor LeqA } & 62 & 59 & 53 & 49 & 47 & 44 & 41 & 37 & 32 & 27 & 23 & 18 \\
\hline \multicolumn{7}{|c|}{ Total outdoor LeqC } & 76 & 73 & 70 & 67 & 65 & 63 & 60 & 57 & 53 & 50 & 47 & 44 \\
\hline \multicolumn{7}{|c|}{ Difference outdoors (LeqC - LeqA) } & 14 & 14 & 16 & 18 & 18 & 19 & 19 & 19 & 20 & 23 & 24 & 26 \\
\hline \multicolumn{7}{|c|}{ Total indoor LeqA } & 39 & 37 & 31 & 27 & 25 & 24 & 21 & 18 & 13 & 10 & 9 & 3 \\
\hline \multicolumn{7}{|c|}{ Total indoor LeqC } & 67 & 65 & 62 & 59 & 57 & 55 & 52 & 49 & 45 & 42 & 39 & 36 \\
\hline \multicolumn{7}{|c|}{ Difference indoors (LeqC - LeqA) } & 28 & 29 & 32 & 32 & 31 & 31 & 31 & 31 & 32 & 32 & 30 & 33 \\
\hline
\end{tabular}

(*) calculated exceeding of limit value indoors (according to HN30:2009). 


\section{Conclusions}

Summing up the existing experience until there is no verified noise calculation method of low frequency noise for Lithuanian conditions, according to the recent literature concerned the following conclusions can be drawn:

- Referring to Danish experts, for calculation of outdoor sound propagation the semi-analytical methods Nord 2000 or Harmonoise are most suitable.

- To obtain calculations corresponding to the HN 30:2009 requirements, the use of the outdoorindoor SPL difference from Table 5, row 2 is recommended. In order to get more accurate results of indoor SPL (e.g. for certain locations of the room) more advanced methods should be used (e.g. finite element method FEM).

According to the calculations the following conclusions can be drawn:

- Standard ISO 1996-2 does not describe the position of windows (opened or closed) for measurements. There is a big possibility that $\mathrm{L}_{\text {CeqT }}$ and $\mathrm{L}_{\text {AeqT }}$ indoors with slightly opened windows will differ less than $20 \mathrm{~dB}$ and HN30:2009 limit values will not be applicable. In that case noise limits of $\mathrm{L}_{\text {night }}(45 \mathrm{dBA})$ will be used. In our hypothetical case, $\mathrm{L}_{\text {night }}$ of 45 $\mathrm{dBA}$ zone will be at the $480 \mathrm{~m}$ distance from the wind turbine;

- In our hypothetical case, difference, greater than $20 \mathrm{~dB}$ between $\mathrm{L}_{\mathrm{CeqT}}$ and $\mathrm{L}_{\mathrm{AeqT}}$, will be met indoors with closed windows and the limit values will be exceeded at a distance greater than $1.5 \mathrm{~km}$. If tonal noise exists, (like in our case at $160 \mathrm{~Hz} 1 / 3$ oct. centre frequencies) the over-regulatory impact distance of low frequency noise will be greater than $2 \mathrm{~km}$ (according to HN30:2009, limit values reduce in $5 \mathrm{~dB}$ ). If we set a wind farm with wind turbines generating low frequencies like in our hypothetical case, the over-regulatory impact distance can exceed 2.5-3 km and more. Such distances already are a problem in the territory planning. It should be noted, that in reality, such acoustical situation in a big distance is possible only at very quiet night time in rural areas, with very low background noise levels, without any additional sounds like wind, rustling trees, traffic noise etc. If we set a wind turbine generating a minimal amount of low frequencies from DELTA measurements, the over-regulatory impact distance of low frequency noise will be $100 \mathrm{~m}$ from an $80 \mathrm{~m}$ hub high turbine.

\section{References}

"Night noise guidelines for Europe", World Health Organization (WHO), Copenhagen, 2009

Bekendtgørelse om støj fra vindmøller" (Statutory order on noise from wind turbines), Bekendtgørelse nr.
1284 af $15 / 12 / 2011$, Danish Ministry of the Environment (DME), 2011

BERGLUND B., LINDVALL T., SCHWELA D. H.. Guidelines for community noise, World Health Organization, Geneva, 1999.

BRONESKE SYLVIA. "Comparison of Wind Turbine Manufacturers' Noise Data for Use in Wind Farm Assessments" Third International Meeting on Wind Turbine Noise, Aalborg Denmark 17 - 19 June 2009.

CASELLA STANGER REPORT. "Low Frequency Noise. Technical Research Support for DEFRA Noise Programme". 2001.

DEPA 1997, Lavfrekvent støj, infralyd og vibrationer i eksternt miljø" (Low frequency noise, infrasound and vibrations in the external environment), Orientering fra Miljøstyrelsen, nr. 9, Danish Environmental Protection Agency, 1997.

HOFFMEYER DAN, JAKOBSEN JØRGEN. "Sound insulation of dwellings at low frequencies" Journal of Low Frequency Noise, Vibration and Active Control, 2010.

Hygiene norm HN 30:2009 "Infrasound and low frequency sounds: Limit values for residential and public buildings"

Hygiene norm HN 33:2011 " Noise limit values for residential and public buildings and they surrounding"

IEC TS 61400-14 "Wind turbines - Part 14: Declaration of apparent sound power level and tonality values".

ISO 13347-3:2004 "Industrial fans. Determination of fan sound power levels under standardized laboratory conditions. Part 3: Enveloping surface methods".

ISO 1996-2:2007 "Acoustics. Description, measurement and assessment of environmental noise. Part 2: Determination of environmental noise levels" (ISO 19962:2007);

ISO 3743-1:2010 “Acoustics. Determination of sound power levels and sound energy levels of noise sources using sound pressure. Engineering methods for small movable sources in reverberant fields. Part 1: Comparison method for a hard-walled test room".

ISO 3744:2010 "Acoustics. Determination of sound power levels and sound energy levels of noise sources using sound pressure. Engineering methods for an essentially free field over a reflecting plane",

ISO 3745:2003 "Acoustics. Determination of sound power levels of noise sources using sound pressure. Precision methods for anechoic and hemi-anechoic rooms".

ISO 3746:2010 "Acoustics. Determination of sound power levels and sound energy levels of noise sources using sound pressure. Survey method using an enveloping measurement surface over a reflecting plane".

JABBEN JAN, VERHEIJEN EDWIN. Options for assessment and regulation of low-frequency noise. Proceedings of the conference on Low Frequency Noise 2012 Stratford upon Avon, UK 22 -24 May 2012.

JAKOBSEN JØRGEN..”Danish regulation of low frequency noise from wind turbines". Proceedings of the conference on Low Frequency Noise 2012 Stratford upon Avon, UK 22 -24 May 2012

KERKERS A.J. AND KOFFEMAN A.I. "Beoordeling van Windturbinegeluid: technische rapportage. Continu, fluctuerend of impulsachtig?" ("Assessment of wind turbine sound: technical report. Continuous, fluctuating or impulsive?", report R060480aaA2.tk, Lichtveld Buis \& Partners bv, Utrecht (in Dutch) 2002. 
LENCHINE V. V. "Amplitude modulation in wind turbine noise". Proceedings of ACOUSTICS 2009 Adelaide, Australia, 23-25 November 2009.

LST EN 61672-1:2003 "Electroacoustics. Sound level meters. Part 1: Specifications“ (IEC 61672-1:2002).

LST EN ISO 266:1999 "Acoustics. Preferred frequencies" (ISO 266:1997).

LST ISO 1996-1:2003 “Acoustics. Description, measurement and assessment of environmental noise. Part 1: Basic quantities and assessment procedures" (ISO 19961:2003).

LST ISO 1996-2:2008 “Acoustics. Description, measurement and assessment of environmental noise. Part 2: Determination of environmental noise levels" (ISO 19962:2007).

MADSEN K. D., PEDERSEN T. H., "Low frequency noise from large wind turbines - Final report", 2010, AV 1272/10, Delta.

MARTIN VAN DER BERG. "Health based guidelines for wind turbine noise in the Netherlands". Proceedings of Fourth international meeting on wind turbines noise, Rome Italy 12-14 April 2011.

MCALEER SINÉAD, FEHILY TIMONEY, MCKENZIE ANDREW, MCKENZIE HAYES. 'Guidance Note on Noise Assessment of Wind Turbine Operations at EPA Licensed Sites (NG3)". Environmental Protection Agency, Office of Environmental Enforcement, June 2011

MØLLER H., PEDERSEN C. S., "Low-frequency noise from large wind turbines", Journal of the Acoustical Society of America, 126 (6), 3727-3744, 2011.

O’NEAL R. D., HELLWEG R. D., LAMPETER R. M., A Study of Low Frequency Noise and Infrasound from Wind Turbines, Report No. 2433-01, July 2009

OLIVA D, HONGISTO $\mathrm{V}$, KERÄNEN J, KOSKINEN. "Measurement of low frequency noise in rooms, Indoor Environment Laboratory", Turku, Finnish Institute of Occupational Health, Helsinki, Finland, 2011;

PEDERSEN CHRISTIAN SEJER, MØLLER HENRIK, PEDERSEN STEFFEN. "Low-frequency noise from large wind turbines - additional data and assessment of new Danish regulations". Proceedings of the conference on Low Frequency Noise 2012 Stratford upon Avon, UK 22 -24 May 2012.

PLOVSING BIRGER. "Low frequency noise from Large Wind turbines. Selection of a propagation model" DELTA, 2008.
SONDERGAARD BO. "Low Frequency Noise from Large Wind Turbines. Sound Power Measurement Method". Danish Electronics, Light an Acoustics, April 2008.

SØRENSEN THOMAS. "Experiences with the New Danish Rules for the Calculation of Low Frequency Noise from Wind Turbines". EMD International A/S. Proceedings of the conference on Low Frequency Noise 2012 Stratford upon Avon, UK 22 -24 May 2012.

VAN DEN BERG G. P. "Effects of the wind profile at night on wind turbine sound". Journal of Sound and Vibration, 277, 955-970, 2004. http://dx.doi.org/10.1016/j.jsv.2003.09.050

VAN DEN BERG G.P. "The sound of high winds: the effect of atmospheric stability on wind turbine sound and microphone noise". University of Groningen, Dissertation, 2006.

WAGNER S., BARRIE R., GUIDATI G. "Wind turbine noise", Springer Berlin, ISBN 3-540-60592-4, 1996.

WATANABE T., MOELLER H., "Low Frequency Hearing Thresholds in Pressure Field and in Free Field", Journal of Low Frequency Noise and Vibration, Vol. 9 No. 31990.

Darius Šaliūnas - PhD student at Kaunas University of Technology, Technological System Diagnostic Institute.

Main research area: low frequency sound, infrasound research.

Address: Kestucio st. 27, 3004 Kaunas Lithuania

Tel.: +370-37-323241, Mob. tel.: +370-616-

37145

E-mail: darius.saliunas@stud.ktu.lt

Vitalijus Volkovas - Prof. Dr. Habil. Director of Technological System Diagnostic Institute.

Main research area: vibration and noise research, systems identification, state diagnostics and monitoring

Address: Kestucio st. 27, 3004 Kaunas Lithuania

Tel. $+370-37-323720$

E-mail: vitalijus.volkovas@ktu.lt 


\title{
Vẻjo jẻgainių generuojamo žemų dažnių triukšmo vertinimo analizè. Poveikio atstumo skaičiavimai atsižvelgiant ị higienos normą HN 30:2009
}

\author{
Darius Šaliūnas, Vitalijus Volkovas \\ Technologiniu sistemu diagnostikos institutas, KTU
}

(gauta 2013 m. sausio mèn., priimta spaudai 2013 m. kovo mèn.)

Nuo 2010 metų sausio 1 d. Lietuvoje įsigaliojo higienos norma HN 30:2009 „Infragarsas ir žemo dažnio garsai: ribiniai dydžiai gyvenamuosiuose ir visuomeninès paskirties pastatuose“. Naujos ūkinès veiklos ar teritoriju plètotojai (tarp ju ir vejjo jègainių statytojai) susiduria su problema: kaip teisingai apskaičiuoti (ivertinti), kokie infragarso ir žemo dažnio garso lygiai bus kaimynystėje (pastatų viduje) ir kaip neviršyti reglamentuojamų dydžių. Kadangi Lietuva, kaip ir daugelis kitų šalių, neturi patvirtinto skaičiavimo metodo, remiantis naujausia literatūra, straipsnyje apžvelgiami pagrindiniai infragarso ir žemų dažnių garso vertinimo klausimai, išryškinamos pagrindinès problemos ir teikiamos kai kurios rekomendacijos skaičiavimams atlikti. Straipsnyje dažniausiai remiamasi Danijoje atliktų tyrimų rezultatais (ši šalis pirmoji (nuo 2012 m.) įsidiegè supaprastintą vèjo jègainių keliamo žemų dažnių triukšmo skaičiavimo metodą, prieš tai atlikusi daugybę tyrimų). Papildomai straipsnyje pateikiami skaičiavimai, kurie rodo, jog, atsižvelgiant i vėjo jègainę lygioje vietovèje, atstumas, kuriame gali būti viršijami ,iprastuose“ gyvenamuosiuose namuose HN 30:2009 reglamentuojami dydžiai, gali kisti nuo $100 \mathrm{~m}$ iki $2 \mathrm{~km}$ ir daugiau. 